\title{
Trade Versus Security: How Countries Balance Technology Transfers with China
}

\author{
Tai Ming Cheung and Bates Gill
}

\begin{abstract}
Apart from a short period in the 1980s, the People's Republic of China has been almost completely excluded from access to military and sensitive dual-use civilian-military technologies from the United States and its allies. But in an era of globalization and convergence in the civilian and military technological domains, this compartmentalization of the economic and security arenas has become increasingly difficult to maintain and justify. Major trading countries are caught in the dilemma of balancing restrictions on high technology and other sensitive trade and investment with China against the benefits of deeper ties with the world's second-largest economy. In examining the trade-offs between economics and national security for the United States, the European Union, Israel, and Japan, it becomes clear that China's rise and growing economic and strategic influence introduce new complexities and challenges for controlling militarily relevant technology and knowledge transfers. KEYWORDS: China, Israel, Japan, technology transfer, export control regimes, trade-security trade-off
\end{abstract}

Apart from a short period in the 1980s, the People's Republic of China has been almost completely excluded from access to military and sensitive dual-use civilian-military technologies from the United States and its allies because of political and strategic considerations. But in the contemporary era defined by globalization and convergence in the civilian and military technological domains, this compartmentalization of the economic and security arenas is becoming increasingly difficult to maintain and justify, generating intensive debate about the future of national security controls on high-technology trade and investment (Committee on Science, Security, and Prosperity 2009). Major trading countries are caught in the dilemma of 
balancing restrictions on high-technology and other sensitive trade and investment with China against the benefits of deeper ties with the world's second-largest economy.

These efforts to limit technology transfers to China are influenced by many of the same factors that influence the ability to impose economic sanctions and other political and strategic embargoes. These factors include well-known coordination and implementation problems at the international level. ${ }^{1}$ At the domestic level, there is also the well-known structural bias against the imposition of export controls because of concentrated costs-which incentivize opponents of these measures to stop their implementation-and diffuse security benefits that dilute the incentives for proponents to act. Only in cases where security interests are well organized, politically influential, and supported by a threatening security environment-or an environment perceived as threatening-would we expect robust controls (Bertsch and Elliott-Gower 1992; Crawford 1995; Cupitt 2000, chap. 1).

A key part of China's modernization and innovation strategy has been to engage with the world economy through trade, investment, and access to global high-technology leaders. While it is sometimes difficult to explicitly identify the causal links between China's engagement with high-technology leaders on the one hand and the country's military modernization on the other, the line between sectors with and without military relevance is becoming harder to distinguish. As the cases show, this technological convergence is itself a distinctive factor affecting dual-use export control regimes and the difficulty in implementing them.

Moreover, China's growing economic weight has fundamentally changed the decisionmaking calculus of its trading partners. When export controls were first imposed through the Coordinating Committee for Multilateral Export Controls (COCOM), Western countries could pursue a broad strategy of denial. It was possible to effectively deny "the East" access to certain technologies, including many civilian or dual-use technologies, to prevent military development in part because "the West" was not reliant on "the East" for its consumer products or lucrative investment opportunities (National Research Council 1991). However, the situation is far more complicated today: China is now the largest trading partner to some 124 countries around the world as of 2011 and surpassed the United States to become the world's largest trader in goods in early $2013 .^{2}$ 
But, at the same time, China's technological development and its emergence as an important trade and investment partner for Europe, the United States, Japan, South Korea, and many others-both as a market for technology and investment as well as the source for more high-tech consumer products and investments-come at a time of increased concern about the direction of Chinese foreign and security policy. China's defense modernization has benefited considerably from external technology transfers to the extent that the country may have been able to narrow its strategic technology gap with the world's advanced military powers by at least one generation or more in critical areas. A range of high-technology sectors, such as information and communications technology, aviation and aerospace, advanced materials sciences, and nanotechnology, which are intensively traded and exchanged across borders-through physical transfers as well as through oral or electronic means, known as "intangible technology transfers"-have applications for military end use. Importantly, these technologies figure prominently in the development of power projection and asymmetrical capabilities that are the Chinese capabilities of increasing concern to the United States and regional states.

In this symposium we examine the economics versus national security trade-offs of engagement with China through a political analysis of how the European Union, Japan, and Israel have made strategic decisions in choosing to engage or not engage China in high-technology trade. ${ }^{3}$ These cases show an increasing trend in conflicting internal and external pressures and dilemmas states face in dealing with a rising China and the intensifying strategic competition surrounding its growing presence in the international order. These dilemmas can also be found in the United States, whose role in shaping the trade versus security approach toward China will be discussed next, which will then be followed by an examination of the nature of the challenges and results that countries have faced in their technology trade engagement with China.

\section{The Pivotal Role of the United States in Shaping the Trade Versus Security Approach to China}

The trade versus national security paradigm shaping technology trade and investment relations with China has primarily been designed by the United States, usually in consultation and coordination with its 
allies. Despite the rapid expansion in bilateral commercial economic relations, the United States in a number of areas has sought tightened controls against China amid growing strategic competition and concern that China is successfully circumventing these controls. A key part of this more stringent regime was the adoption of the "China Rule" in 2007 that put in place new licensing mechanisms for military end use and other national security-deemed items (Fergusson 2009, 23-26). China claims that the United States has imposed restrictions on more than 2,400 types of technological products that can be exported to China (China Daily, May 4, 2012). This appears to have had a significant impact on technology trade between the two countries. Chinese imports of high-technology goods from the United States as a share of total high-technology imports have fallen from 18 percent in 2001 to 6.3 percent in 2011, which Chinese officials blame specifically on US export controls (China Daily, November 17, 2012). During the United States-China summit meeting in June 2013, Chinese President Xi Jinping specifically called on the United States to lift restrictions on high-technology exports to China (Xinhua, June 9, 2013).

While the United States has been the driving force in establishing export controls against China, this has not been an easy task. With its growing economic clout, China has been making concerted efforts to overcome these restrictions by targeting weak links in the export control chain. Moreover, the blurring of the civilian and military technological domains has seriously complicated the ability to police this high-technology trade both to ensure that damaging leakages do not occur and to prevent the imposition of overly draconian restrictions that might impact the broader commercial trading relationship.

For example, a study by Hugo Meijer (2013) on the politics of US export control policy toward China identifies the policy contests between different coalitions. On one side of the divide in the post-Cold War era are conservative "control hawks" who advocate the implementation of stringent export controls because of fears that transfer of sensitive technologies to China would damage US national security interests. They frame their arguments in the Cold War paradigm of the trade-off between national security and economic interests.

On the other side is the "Run Faster" coalition that believes stringent unilateral export controls are ineffective and also undermine US national security by weakening the commercial industrial base upon 
which the defense industry is dependent. The Run Faster coalition has sought to move beyond the security versus economics trade-off debate. Their central point is that effective state capacity to enforce export controls is being steadily weakened by globalization, the blurring of civil-military technologies, and a host of other factors. Rather than build ever higher walls to prevent leakages, this coalition advocates a smarter, more streamlined, and targeted export control system that would better support the US technological and industrial base by liberalizing exports so that it could "run faster" than potential competitors. This coalition appears to have gained ascendancy within the Obama administration, which has been seeking to overhaul the US export control system since the late 2000s (Fergusson and Kerr 2013).

\section{The Trade Versus Security Dilemma: \\ Expectations and Findings}

The policy battles within US decisionmaking circles also take place in other countries that have both strategic interests involving China and valuable or potentially valuable economic relations with it. The nature and intensity of these debates and the decisions arising from them will vary depending on five critical factors, three related to the external environment and two to domestic politics.

- First, does China pose a security threat to a given country, and, if so, how important are those threats? Ceteris paribus, we would expect controls to be more robust where the country in question faces immediate security challenges, and less robust in cases where China appears less threatening or where the promise of technology trade might even yield security benefits from increased Chinese cooperation.

- Second, what are the scale and makeup of the country's economic relations with China, and how important are bilateral high-technology trade interactions? The greater the economic complementarities in favor of high-technology trade and investment with China, the more likely that domestic support-typically led by business coalitions and their allies-to engage in such activities is strong.

- Third, what is the country's relationship with the United States? We would expect tighter controls where close bilateral strategic ties give the United States leverage on the issue. 
- Fourth, whether technology trade and export controls are considered to be a matter of high or low politics by a country's ruling elite is highly pertinent. If technology trade with China is viewed as an important political issue, then the greater the possibility that it becomes entangled with other higher-level political considerations, such as human rights and threat perceptions, and prone to interference and disruption from political circles, especially legislative bodies. The United States is a prominent example of this high politics model. If, on the other hand, technology trade with China is regarded as low politics, which has been until now the case in Japan, then there is far less potential for political involvement and the country's bureaucratic agencies are in the driving seat.

- Finally, how capable is the country's national export control regime in carrying out its obligations with respect to multilateral export control regimes? Weak controls may be largely strategic and political, but may also arise from weak monitoring capacity. Such weaknesses may even pertain to particular domains in the advanced industrial states, such as academic cooperation, that are difficult to monitor.

The country studies we examine in this symposium explore these commonsense propositions and provide some evidence for them. First, for large countries and groupings such as the European Union that are geographically distant from China and so do not face direct or pressing security challenges, it is easier to prioritize commercial interests above national security or other strategic considerations. There may be constraints, however, in their choices of how open they can be in their technology trade with China if they are strategically close to and influenced by the United States. For the European Union, commercial interests are the dominant driver in shaping the development of their technology trade relationship with China, but the Europeans have continued to maintain restrictions on most transfers of clearly military-use weapons and technology owing to the arms embargo on China, dual-use controls, human rights concerns, and US pressure not to lift the arms embargo.

A second conclusion is that smaller countries with important strategic and economic linkages with the United States, such as Israel, are indeed susceptible to much greater influence from the United States to exercise constraints in dealing with China, although how far they are willing to do so depends on the amount of pressure 
being applied by Washington. Israel was reluctant to sever its longstanding defense technological relationship with China and only did so after the United States applied enormous pressure and threatened to curtail its defense relationship with Israel. Pakistan is another country that enjoys close strategic ties with both China and the United States, although Islamabad is an importer rather than an exporter of advanced technology to China and has sought to balance its strategic interactions and interests with Washington and Beijing.

Third, trading states such as Japan and South Korea that are in close proximity to China face the starkest dilemmas. They are immediately impacted by China's rising security presence, but at the same time have the greatest economic and trading complementarities with China. Between the 1970s and until the end of the 2000s, these countries were able to effectively manage these competing interests through compartmentalization and prioritizing economic over security interests. The management of technology trade throughout this period and up to the present is in the hands of powerful economic agencies, such as the Ministry of Economy, Trade, and Industry (METI) in Japan, while the national security apparatus has been secondary in influence. This framework is being seriously, perhaps fatally, undermined as strategic and security frictions have spilled over into the economic domain, such as with China's cutoff in the supply of rare earth metals to Japan in 2011, and the growing importance that Japan is placing on enhancing its security posture. Debate about how to come up with a new trade-security framework is in its infancy in Japan as pointed out in the contribution by Tomoo Marukawa, but this will be one of the most profound policy issues that Tokyo will face because it goes to the very heart of the long-term relationship between Japan and China.

\section{Case Studies}

In the larger project from which the articles for this symposium were drawn, authors were asked to examine and detail the level and scope of high-tech trade and investment between China and major economic partners. They then assessed current developments and future prospects of the policy, and regulatory and security debates within these partners regarding their high-tech trade and investment with China. Each of these relationships is different in its own way-for example, in terms of economic complementarities, the scale and nature of bilateral trade and investment, and degrees of 
concern about whether and how high-tech trade and investment may contribute to China's economic competitiveness and military modernization. However, at the same time, common themes emerge across the different cases.

First, in those partners closer geographically to China-such as Japan, South Korea, Taiwan, and, to a lesser degree, Russia-the cases note that security concerns about China are also on the rise and the possible causal linkages between their economic relationship and China's military modernization are gaining greater attention.

Second, with the exception of Russia, none of the economic partners are presently exporting significant quantities of weapons or other known military end-use goods and technologies to China. According to data from SIPRI, however, some European (French) weapons systems are copy- or licensed-produced in China; SIPRI also lists some European (British and German) military maritime and aircraft propulsion systems produced in China.

In a third important commonality-although it is not central to our main argument-the case studies all note that there is increasing concern about how Chinese trade and investment create economic harm, although the nature and intensity of these concerns vary across the cases. These concerns arise from the loss of intellectual property and other proprietary information to Chinese partners and competitors, an increase in Chinese interest to invest in and acquire companies and technologies in the partner countries, and China's increasing competitiveness in certain more advanced sectors such as telecommunications.

Fourth, across the cases, the flow in high-tech investment and collaboration has become far less unidirectional over time. Increasingly, Chinese investors and researchers are more active in channeling resources into opportunities abroad. While Chinese investment has in the past been largely focused in the developing world, the cases also provide evidence for increased Chinese interest to invest in and acquire European, Japanese, South Korean, and Israeli assets, technologies, and know-how. The scrutiny of foreign investment flows often falls outside the existing export control regimes of these countries, but it is now receiving closer scrutiny as technology transfer is recognized as a significant channel that can operate quite separately from goods trade.

Nevertheless, in a fifth common theme, we find that economic imperatives and interests mostly trump security concerns, even in cases where there are growing anxieties about China's growing mili- 
tary power and greater economic competitiveness-such as in Japan. Among the cases, only Israel can be said to have had its sensitive trade with China cut off owing to security concerns-but this was primarily a result of US, not internal Israeli, pressure to halt specific weapons exports to China. Indeed, within Israel arguments were made that weapons sales to China could enhance Israeli security to the degree they opened doors in China (arms exports to China were carried out well before formal diplomatic relations began between the two) and could somewhat moderate Chinese arms transfers to adversaries of Israel in the Middle East. In Russia, security concerns have been raised in some quarters about the wisdom of providing China with advanced weapons systems and dual-use technologies that have contributed so significantly to China's military modernization. But these security concerns have not significantly limited Russian exports or the benefit they bring to the Russian economy. In this case, the arms industry has maintained significant political clout that permits it to override larger strategic qualms.

Japan presents an especially interesting case in this regard as the bilateral economic relationship remains deeply important to both sides-Japan is China's largest source of imports and China is Japan's largest overall trading partner. Yet, at the same time, the security relationship between the two has steadily deteriorated in recent years. At present, however, the internal political and regulatory environment in Japan has not moved to significantly scrutinize or curtail high-technology trade and investment with China. Indeed, high-technology trade and investment with China have remained steady over the past five to six years. This appears to reflect a reluctance to impair the economic benefits of trade with China and a perception that such relations do not have a major impact on China's military modernization efforts.

\section{Europe, Japan, Israel}

The China-EU high-tech relationship, analyzed in the next article by Oliver Bräuner, is especially important to consider. Not only is the European Union China's number one trading partner, but China is the European Union's second-largest trading partner behind the United States. And, importantly, while direct transfers of military systems and technologies have largely been cut off since the announcement of the EU arms embargo in June 1989, EU member states have been significant suppliers of high-technology trade and investment for 
China. The Chinese Ministry of Commerce has identified the European Union as China's "largest source of technology imports"including in such dual-use areas as aerospace, information technologies, materials sciences, nuclear physics, and others.

This is possible, according to Bräuner, not only because China is a lucrative market for European exporters and investors, but also because the system of export controls to which EU countries are subjected has sufficient leeway and lack of consistency to allow for potentially militarily relevant exports to China and others. Moreover, China is not really seen as a principal "target" for export controls among EU countries as these controls are primarily concerned with weapons of mass destruction-related transfers to countries of particular concern and terrorist organizations. As a result, the author's interviews suggest only about 10 percent of dual-use export license applications for EU member state transfers to China are denied. As in other cases, the economic value of China-EU high-technology trade and investment simply outweighs security considerations. Owing to geographic distance and the lack of direct security interests in the Asia-Pacific, Europeans do not generally see China as a major security threat.

The China-EU relationship also reflects trends seen in other cases-growing outbound Chinese investments to their major partners. Chinese investment in Europe has grown considerably in just a few years' time-from less than US $\$ 1$ billion in 2008 to more than US $\$ 10$ billion in 2012, a figure nearly US $\$ 4$ billion higher than Chinese investment in the United States. The EU case is also interesting for the extensive nature of high-technology transfers to China: these take place not only on a business-to-business basis, but through an array of public and private exchanges via universities and joint research and development centers.

At the same time, owing to China's greater competitiveness and reports of growing Chinese economic espionage, there is some increased concern in parts of the EU over the negative economic and security implications of high-technology trade and investment relations with China. But these concerns are far from mainstream. As Bräuner concludes in his case study, China is by and large not seen in Europe as a security threat and the China-EU relationship is principally defined by commercial matters of trade and investment. A coherent strategy for finding a balance between the economic and security concerns of trade and investment relations with China will 
remain elusive and largely dominated by the advancement of economic interests.

In his article, Marukawa details the extensive trade and investment relationship between China and Japan and how it has grown dramatically in the past two decades. In 2009, China became Japan's largest trading partner for both imports and exports, and by 2011, 22 percent of Japanese exports and 20 percent of Japanese imports were with China (by comparison, exports to and imports from the United States accounted, respectively, for 16 percent and 9 percent). Over much of the past twenty years, the share of high-tech goods in this trade increased dramatically, first as Japan exported such goods to China and later as China exported high-tech goods to Japanalthough in the latter instance, these were largely goods, such as computers, where China's final assembly of the product was at the low-value-added end of the production chain.

With the end of COCOM strictures in the mid-1990s, Japan stepped up its exports of advanced machinery and technologies to China, and today, according to calculations by Marukawa, around 13 to 15 percent of Japanese exports to China could be considered "sensitive" owing to their potential for use in developing military systems, including items such as integrated circuits and machine tools. He notes too that while there are some mechanisms in place to regulate and restrict "technology leakage" and foreign investment in certain sensitive sectors in Japan, these forms of technology acquisition by China nonetheless persist and are probably on the rise. And, while concerns are expressed in political and business circles about the need for Japan to be more cautious in its high-tech and dual-use trade and investment relations with China, no formal regulatory action has been forthcoming to date. In short, this article concludes that, in spite of increasing tensions between Japan and China, as well as growing apprehensions within Japan about China as both an economic competitor and security threat, the flows of trade and investment between Japan and China have not been commensurately restricted. This results from a complex mix of bureaucratic politics, pressures from the business community, and a perception in Japan that high-technology trade and investment with China do not make a significant contribution to Chinese military modernization.

Yoram Evron contributed the article on the China-Israel relationship, which is distinct from the China-Japan and China-EU cases. Perhaps most interesting is the fact that well prior to the establish- 
ment of China-Israel relations in 1992, Israel was providing military technology to China. This practice continued through 2005.

Owing in part to its diplomatic isolation and strong security and defense institutions, Israel's early high-technology and militaryrelated exports to China were overseen and approved by the Israeli Ministry of Defense. Between 1979 and 1999, the two countries agreed to some sixty military technology deals with an estimated value of US $\$ 1$ to $\$ 2$ billion. Apparently, these deals included T-59 tank upgrades, night vision systems, radio systems, electronic warfare systems, air-to-air missiles, Lavi fighter technology, and antiradar assault UAVs. By and large, these transfers were in relatively small numbers resulting in a "qualitative" rather than "quantitative" improvement for Chinese military modernization.

However, with the cancellation of the Phalcon airborne early warning deal in 2000 and the Harpy UAV maintenance deal in 2005, the United States insisted on and achieved a complete suspension of all military technology transfers to China. As a result, other forms of military-to-military engagement between Israel and China have slowed and Israel's technology transfers to China became subject to tight screening mechanisms and self-imposed restrictions.

At the same time, China has remained interested in Israeli high technology-particularly in such areas as medical equipment, information and telecommunications, agricultural technology, control and measurement equipment, and clean energy, some of which could have military applications-and has continued to seek access to it, through imports, through joint scientific and R\&D projects, and through some limited Chinese investments in Israel. For example, from 2000 to 2012, total trade between China and Israel grew dramatically from US $\$ 860$ million to US $\$ 6.8$ billion, with approximately 50 to 60 percent of Israeli exports in the last several years considered advanced technology.

Evron concludes that while high-technology transfers have been a part of China-Israel relations for decades, the most important and extensive transfers were probably those prior to 2005 in the military realm. Today, tightened export controls, growing concerns about Chinese intellectual property violations and US reactions, and Chinese suspicions about close US-Israel ties all contribute to limiting the potential for China-Israel high-technology trade and investment relations. This is certainly the case for military and dual-use technologies, but also in advanced civilian technologies. As in other cases, the 
biggest growth area in the near term will likely be Chinese investments in the high-technology sector in Israel.

In sum and looking ahead, export control regimes now constitute an important feature of the international political economy and have done so for many decades. But the Chinese case provides a particularly rich area for study, showing how in today's globalized world strategic and economic concerns interact and affect national priorities and policies concerning high-technology trade and investment. Although the broad literature on export controls and sanctions provides interesting analytic clues on how to advance an understanding of this phenomenon, China's rise and growing economic and strategic influence introduce new complexities for analysis, including the domestic politics of security policies-how these issues fit into existing political cleavages-and the emergent challenges inherent in controlling militarily relevant technology and knowledge transfers. As this symposium shows, much of the existing debate, scholarship, and policy on strategic technology trade and export controls are a throwback to the Cold War and early post-Cold War eras and of limited and decreasing current value. The trade control regimes in the United States and other major powers are similarly relics of a bygone era that are struggling to adapt to new realities. China is working hard to take full advantage of this fragmented and outdated system.

Tai Ming Cheung is the director of the University of California's Institute on Global Conflict and Cooperation and associate professor in residence at the School of International Relations and Pacific Studies, University of California, San Diego.

Bates Gill is chief executive officer of the United States Studies Centre at the University of Sydney. He was previously director of the Stockholm International Peace Research Institute ([SIPRI], 2007-2012), held the Freeman Chair in China Studies at the Center for Strategic and International Studies (2002-2007), and was the inaugural director of the Center for Northeast Asian Policy Studies at the Brookings Institution (1998-2002).

\section{Notes}

1. The Stockholm International Peace Research Institute (SIPRI) maintains an extensive database and carries out ongoing research and analysis on multilateral arms embargoes: www.sipri.org/research/armaments/transfers /controlling/embargoes. On the challenges of effective implementation of multilateral arms embargoes, see Fruchart et al. 2007. 
2. Bao Chang, "China Continues to Increase Influence on Global Trade," China Daily, January 11, 2013, www.chinadaily.com.cn/business /2013-01/11/content_16105777.htm; "China Eclipses U.S. as Biggest Trading Nation," Bloomberg, February 11, 2013, www.bloomberg.com/news /2013-02-09/china-passes-u-s-to-become-the-world-s-biggest-trading -nation.html.

3. The University of California's Institute on Global Conflict and Cooperation (IGCC) and the Stockholm International Peace Research Institute (SIPRI) organized a workshop in 2012 to look at seven cases of Chinese high-tech trade and investment relations with key partners: Brazil, the European Union, Israel, Japan, Russia, South Korea, and Taiwan.

\section{References}

Bertsch, Gary, and Steven Elliott-Gower, eds. 1992. Export Controls in Transition: Perspectives, Problems, and Prospects. Durham: Duke University Press.

Committee on Science, Security, and Prosperity. 2009. Beyond "Fortress America": National Security Controls on Science and Technology in a Globalized World. Washington, DC: National Academies Press.

Crawford, Beverly. 1995. "Hawks, Doves, but No Owls: International Economic Interdependence and Construction of the New Security Dilemma." In On Security, ed. R. Lipschutz. New York: Columbia University Press.

Cupitt, Richard T. 2000. Reluctant Champions: U.S. Presidential Policy and Strategic Export Controls, Truman, Eisenhower, Bush, and Clinton. London: Routledge.

Fergusson, Ian. 2009. The Export Administration Act: Evolution, Provisions, and Debate. Washington, DC: Congressional Research Service.

Fergusson, Ian, and Paul Kerr. 2013. The U.S. Export Control System and the President's Reform Initiative. Washington, DC: Congressional Research Service.

Fruchart, Damien, Paul Holtom, Siemon T. Wezeman, Daniel Strandow, and Peter Wallensteen. 2007. United Nations Arms Embargoes: Their Impact on Arms Flows and Target Behaviour. Stockholm: SIPRI.

Meijer, Hugo. 2013. "Trading with the Enemy: The Making of U.S. Export Control Policy Toward the People's Republic of China." PhD diss., Institut d'Etudes Politiques (Sciences Po), Paris.

National Research Council. 1991. Finding Common Ground: U.S. Export Controls in a Changed Global Environment. Washington, DC: National Academies Press. 